\title{
HORMONAL REQUIREMENTS OF THE DIFFERENT CYCLES OF THE SEMINIFEROUS EPITHELIUM DURING REINITIATION OF SPERMATOGENESIS IN LONG-TERM HYPOPHYSECTOMIZED RATS*
}

\author{
R. G. VERNON, $\uparrow$ V. L. W. GO $\ddagger$ AND I. B. FRITZ $\ddagger$ \\ Banting and Best Department of Medical Research, University of Toronto, \\ 112 College Street, Toronto, Canada M5G $1 L 6$
}

(Received 20th May 1974)

Summary. Restoration of testicular function in long-term hypophysectomized rats given different hormonal treatments during the various cycles of the seminiferous epithelium was evaluated on the basis of the weights of testes, epididymides, and other accessory sexual glands, histological examination of testes, and determination of the numbers of spermatozoa/epididymis. The Staput fractionation technique for the separation of classes of germinal cells was employed to provide a measure of the advancing front of pulse-labelled cells following the intratesticular administration of $\left[{ }^{3} \mathrm{H}\right]$ thymidine. The results suggested that during the first two cycles, in which spermatogonia develop into pachytene spermatocytes, either LH or testosterone alone was sufficient for partial restoration. During the third cycle of the seminiferous epithelium, LH and FSH were required to allow previously labelled pachytene spermatocytes to progress efficiently to stage 7 spermatids. Administration of $\mathrm{LH}$ alone during the final cycle was sufficient to permit stage 7 spermatids to develop into spermatozoa, provided LH + FSH had been given during the previous three cycles. Injection of LH during the entire period and of FSH during the third cycle of the seminiferous epithelium was required to achieve Staput profiles characteristic of a normal advancing front of pulse-labelled cells, and to allow partial restoration of spermatogenesis. More complete restoration was obtained in rats given FSH and $\mathrm{LH}$ during the first three cycles but, with the doses employed, the number of spermatozoa/testis remained subnormal. Efficient completion of each cycle of the seminiferous epithelium appeared to be hormone-dependent. The data are discussed in relation to the possibility that hormones may affect the general development of germinal cells in an indirect manner by their influence on Sertoli cell function.

\footnotetext{
* Reprint requests and correspondence to Dr I. B. Fritz.

$\dagger$ Present address: Hannah Research Institute, Ayr, Scotland.

$\ddagger$ Present address: Mayo Clinic, Rochester, Minnesota 55901, U.S.A.
} 


\section{INTRODUCTION}

In rat testes, four cycles of the seminiferous epithelium are required for the formation of spermatozoa from type $A_{1}$ spermatogonia. The first cycle consists of the production of resting or preleptotene spermatocytes from type $A_{1}$ spermatogonia; the second, the transition of preleptotene spermatocytes to pachytene spermatocytes (stage VII); the third, the formation of stage 7 spermatids from stage VII pachytene spermatocytes; and the last, the maturation of stage 7 spermatids into spermatozoa (Clermont, 1972). Each cycle requires 12 to 13 days in the rat, the entire process lasting 48 to 52 days, depending on the strain (Clermont, 1972).

It is well known that hypophysectomy of rats results in an arrest of spermatogenesis and that this can be reinitiated in adult rats by treatment with $\mathrm{LH}+$ FSH (for reviews, see Clermont \& Harvey, 1967; Steinberger, 1971). A quantitative study of spermatogenesis in hypophysectomized rats was undertaken by Clermont \& Morgentaler (1955), but attempts to elucidate the precise sites at which specific hormones are required to restore spermatogenesis in hypophysectomized rats have given rise to conflicting interpretations (Nelson, 1937; Cutuly \& Cutuly, 1940; Albert, 1961; Clermont \& Harvey, 1967; Lostroh, 1971; Steinberger, 1971).

We have reinvestigated the hormonal requirements of the different cycles of the seminiferous epithelium during the reinitiation of spermatogenesis in hypophysectomized adult rats. By a variety of criteria to be described, including results obtained by application of the Staput fractionation technique for the separation of classes of germinal cells (Lam, Furrer \& Bruce, 1970; Go, Vernon \& Fritz, 1971a), we have attempted an evaluation of the degree of restoration of testicular functions in these animals.

\section{MATERIALS AND METHODS}

\section{Animals}

Hypophysectomized male rats, weighing 220 to $240 \mathrm{~g}$, were purchased from the Charles River Breeding Laboratories. They were allowed free access to a commercial rat chow (Rockland) and tap water and were maintained in an air-conditioned room $\left(24^{\circ} \mathrm{C}\right)$ for 30 days. Those rats whose body weight and testicular size at the end of this period indicated that they were not completely hypophysectomized were eliminated from the study.

\section{Analytical procedures}

Rats were killed by cervical dislocation. The testes, prostate, seminal vesicles and epididymides were removed, cleaned of extraneous material and weighed. Weights are presented for testes and epididymides only, since the changes in the weights of prostates and seminal vesicles were in all cases parallel to those observed for the epididymides. The right testis was cut transversely into three parts, and the middle portion of the organ was fixed in Bouin's solution, after which $5 \mu \mathrm{m}$ transverse sections were prepared and stained with periodic acidSchiff (PAS) and haematoxylin by methods previously described (Go et al., 1971a). One of the remaining two portions was gently homogenized by hand 
in phosphate-buffered saline (PBS) (Dulbecco \& Vogt, 1954) to give a $5 \%$ $(w / v)$ homogenate. Samples of the homogenate $(0.05 \mathrm{ml})$ were diluted to 5.0 $\mathrm{ml}$ with PBS and were then filtered and washed as described previously for the determination of radioactivity in DNA in cell suspensions (Go et al., 1971a). The tunica albuginea of the remaining third of the testis was removed, and a pooled cell suspension was prepared for separation by the Staput procedure (Lam et al., 1970; Go et al., 1971a). Duplicate Staput fractionations were always performed, with excellent replication. Results from the current investigation and from those reported earlier (Go et al., 1971a, b) indicated equal incorporation of $\left[{ }^{3} \mathrm{H}\right]$ thymidine into DNA in various portions of the testes, with good agreement among the various groups of rats with respect to the total amounts incorporated. Details concerning the number of Staput fractionations are provided in the legends to the text-figures. A portion of the left testis from each rat was homogenized and assayed for carnitine acetyltransferase (EC 2.3.1.17) (CAT) activity (Vernon et al., 1971). The right epididymis was also homogenized in PBS, and the number of spermatozoa present was determined microscopically with a haemocytometer. The $\left[{ }^{3} \mathrm{H}\right]$ thymidine incorporated into cells in the epididymal homogenate was measured by the same method used for determining radioactivity in testicular cell suspensions. All other procedures were the same as those previously described (Go et al., $1971 \mathrm{a}, \mathrm{b}$; Vernon et al., 1971). The efficiency for counting $\left[{ }^{3} \mathrm{H}\right]$ thymidine incorporated into the DNA of cells was determined as $19 \cdot 3 \%$.

\section{Experimental design}

In order to study the development of a specific group of cells under various hormonal regimens, preleptotene spermatocytes and spermatogonia were pulse-labelled with [ ${ }^{3} \mathrm{H}$ ] thymidine (Monesi, 1962; Clermont \& Harvey, 1965; Monesi, 1965; Lam et al., 1970; Go et al., 1971a), and the progress of these labelled cells was monitored by measuring the amount of radioactivity remaining in the testis and by fractionation of cell suspensions using the Staput technique (Lam et al., 1970; Go et al., 1971a).

The long-term hypophysectomized rats were allotted to various groups, each of which contained six rats. The rats received daily treatment by subcutaneous injection of FSH alone $(100 \mu \mathrm{g} / \mathrm{rat} /$ day $)$ or LH alone $(100 \mu \mathrm{g} / \mathrm{rat} /$ day $)$ or of both FSH and LH for 12 days. During subsequent 12-day periods, the rats received various hormonal treatments, as shown in Table 1 and indicated in the text.

Samples of FSH (NIH ovine FSH-S7, 1.15 FSH-S1 units/mg, containing $0.019 \mathrm{LH}$ units $/ \mathrm{mg}$ ) and LH (NIH ovine LH-S16, $0.99 \mathrm{LH}-\mathrm{S} 1$ units/mg, containing less than $0.019 \mathrm{FSH}$ units/mg) were used.

For some groups of animals, testosterone propionate (TP) ( $3 \mathrm{mg} /$ day/rat) was substituted for LH as indicated in 'Results' and Table 1. Testosterone propionate was purchased from CIBA Company Ltd.

Twelve days after hormonal treatment was initiated, the rats in all groups received an injection of $50 \mu \mathrm{Ci}\left[{ }^{3} \mathrm{H}\right]$ thymidine $(6.7 \mathrm{Ci} / \mathrm{mmol}$, New England Nuclear) in $0.1 \mathrm{ml}$ isotonic saline into the right testis, using a 25-gauge needle. The rats were killed 12, 24, 36 or 48 days later, as indicated in Table 1. 


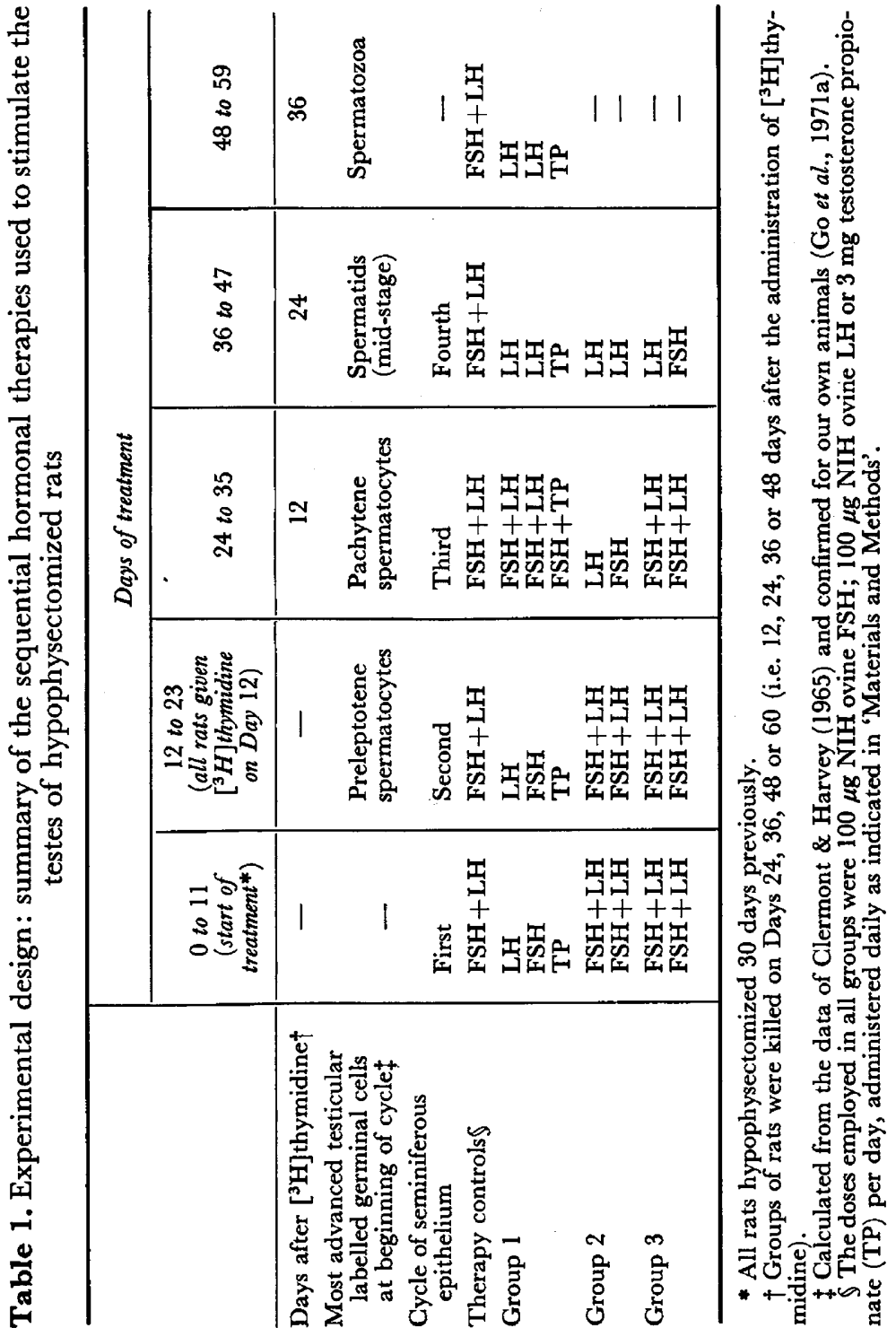


A fixed number of cells $\left(2 \times 10^{7}\right)$ was always applied during a Staput fractionation. The percentage of labelled cells in the total population following $\left[{ }^{3} \mathrm{H}\right]$ thymidine administration varied greatly, depending on the hormonal status of the animal. For example, a very large proportion of cells from testes of untreated, hypophysectomized rats was labelled because of the relatively low number of spermatocytes and spermatids in the total reduced population of testicular cells, and the relatively large proportion of spermatogonia (Go et al., 1971a). Various hormonal therapies increased the relative number of unlabelled cells by permitting the enhanced formation of spermatocytes and spermatids.

To correct for these variations, we have calculated the Staput profiles which would have been obtained if all cells in the total testis had been applied for separation in the Staput fractionation. These corrected values, which are recorded on the right-hand ordinates of Text-figs 1 to 3 , permit a more quanti-

Table 2. Effects of hormonal treatments for 24 days to hypophysectomized rats

\begin{tabular}{|c|c|c|c|c|c|}
\hline Treatment* & No. of rats & $\begin{array}{l}\text { Wt of testis } \dagger \\
(\mathrm{g})\end{array}$ & $\begin{array}{c}\text { CAT activity } \\
(\mu \text { mol NADH } \\
\text { produced/min/ } \\
\text { testis) }\end{array}$ & $\begin{array}{c}{\left[{ }^{3} \mathrm{H}\right] \text { thymidine }} \\
\text { retained in } \\
\text { testicular } D \mathcal{N A} \\
\text { ct/min } \times 10^{-3} / \\
\text { testis) }\end{array}$ & $\begin{array}{c}\text { Wt of } \\
\text { epididymis } \\
(\mathrm{g})\end{array}$ \\
\hline $\begin{array}{l}\text { FSH+LH } \\
\text { LH } \\
\text { FSH } \\
\text { TP } \\
\text { None }\end{array}$ & $\begin{array}{l}9 \\
7 \\
9 \\
4 \\
6\end{array}$ & $\begin{array}{l}0.735 \pm 0.075 \\
0.675 \pm 0.115 \\
0.445 \pm 0.070 \\
0.575 \pm 0.110 \\
0.270 \pm 0.020\end{array}$ & $\begin{array}{l}8.9 \pm 1.1 \\
6 \cdot 8 \pm 1.9 \\
4 \cdot 0 \pm 0.8 \\
6 \cdot 6 \pm 1 \cdot 2 \\
1.0 \pm 0.05\end{array}$ & $\begin{array}{r}229 \pm 27 \\
233 \pm 56 \\
152 \pm 21 \\
178 \pm 15 \\
45 \pm 11\end{array}$ & $\begin{array}{c}0 \cdot 20 \pm 0.005 \\
0 \cdot 20 \pm 0 \cdot 05 \\
0 \cdot 085 \pm 0 \cdot 01 \\
0 \cdot 28 \pm 0 \cdot 065 \\
0 \cdot 075 \pm 0.005\end{array}$ \\
\hline
\end{tabular}

Results are given as means \pm S.E.M.

* The doses of hormones employed were the same as those stated in Table 1.

$\uparrow$ Both testes and both epididymides from each rat were pooled and weighed, and data are expressed as the mean weight/testis or epididymis.

tative comparison of the radioactivity peaks in the Staput profiles of testicular cell suspensions prepared from various groups of hypophysectomized rats given different therapies. The estimated $\mathrm{ct} / \mathrm{min} /$ fraction from the total testis (right ordinate) were calculated according to the equation:

$\frac{(\text { Observed ct } / \mathrm{min} / \text { fraction })(\mathrm{ct} / \mathrm{min} / \mathrm{testis})}{\mathrm{ct} / \mathrm{min} / 2 \times 10^{7} \mathrm{cells}}=\begin{aligned} & \text { Estimated } \mathrm{ct} / \mathrm{min} / \text { fraction from } \\ & \text { total testis. }\end{aligned}$

\section{RESULTS}

Hormonal requirements during the second cycle of the seminiferous epithelium: progression of preleptotene spermatocytes to pachytene spermatocytes

Treatment of hypophysectomized rats for 24 days with $\mathrm{FSH}+\mathrm{LH}$, or with LH, FSH or testosterone propionate alone, as shown in Table 1, Group 1, resulted in marked increases in testicular weight and CAT activity/testis and /g testis (Table 2). The elevated CAT activity suggested that greater numbers of pachytene spermatocytes were being generated (Vernon et al., 1971). This was confirmed qualitatively by microscopic examinations of testis sections. 


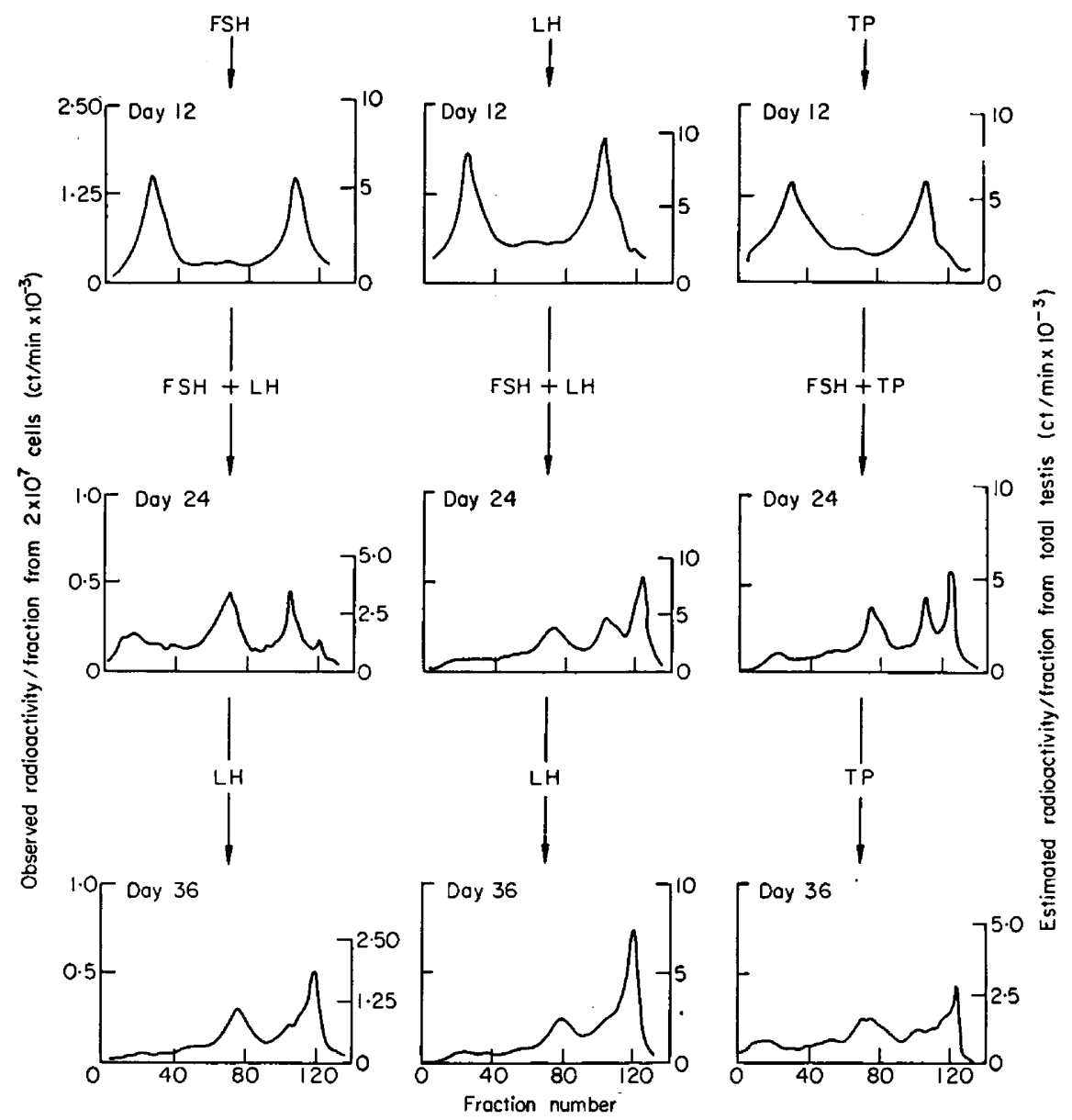

TEXT-FIG. 1. Staput profiles of testicular cells from hypophysectomized rats given various sequential hormonal treatments. For details of experimental procedures, see 'Materials and Methods', and for description of the experimental design, see Table 1. The day shown in each panel refers to the time after $\left[{ }^{3} \mathrm{H}\right]$ thymidine administration, which in all cases is 12 days after beginning the hormone treatments indicated. Each panel represents data from duplicate Staput fractionations of cells obtained from four to six pooled testes of rats treated with hormones cited. The data shown in Text-fig. 1 correspond to experiments performed in Group 1 of Table 1; data in Text-fig. 2 correspond to experiments performed in Group 2 of Table 1, together with the 'therapy controls'; and data in Text.fig. 3 correspond to experiments performed in Group 3 of Table 1, together with the 'therapy controls'. Identification of labelled cells in various fractions has been described previously (Go et al., 197la). For reference, Fractions 103 to 105 contained labelled spermatogonia and preleptotene nuclei and cells having a sedimentation velocity of approximately $2.5 \mathrm{~min} / \mathrm{hr}$; Fractions 25 to 40 contained labelled pachytene spermatocytes having a sedimentation velocity of around $11.5 \mathrm{~mm} / \mathrm{hr}$; Fractions 70 to 80 contained labelled immature spermatids having a sedimentation velocity of about $6 \mathrm{~mm} / \mathrm{hr}$; and Fractions 110 to 125 contained labelled mid- to late-stage spermatids or spermatozoa, depending upon the time after administration of labelled thymidine, having a sedimentation velocity of 1.25 to $1.5 \mathrm{~mm} / \mathrm{hr}$. In each case, the origin was standardized at Fraction 135. 
The retention of $\left[{ }^{3} \mathrm{H}\right]$ thymidine in testicular DNA was also greatly increased by all four treatments (Table 2), presumably in association with a reduced loss of labelled cells. Staput profiles on Day 24 (12 days after thymidine) showed a similar distribution of radioactivity following FSH, LH or testosterone propionate therapy (Text-fig. 1), or FSH $+\mathrm{LH}$ therapy (Text-fig. 2). The cells appearing in Fraction 30 consisted of labelled pachytene spermatocytes, confirming previous observations (Go et al., 1971a):

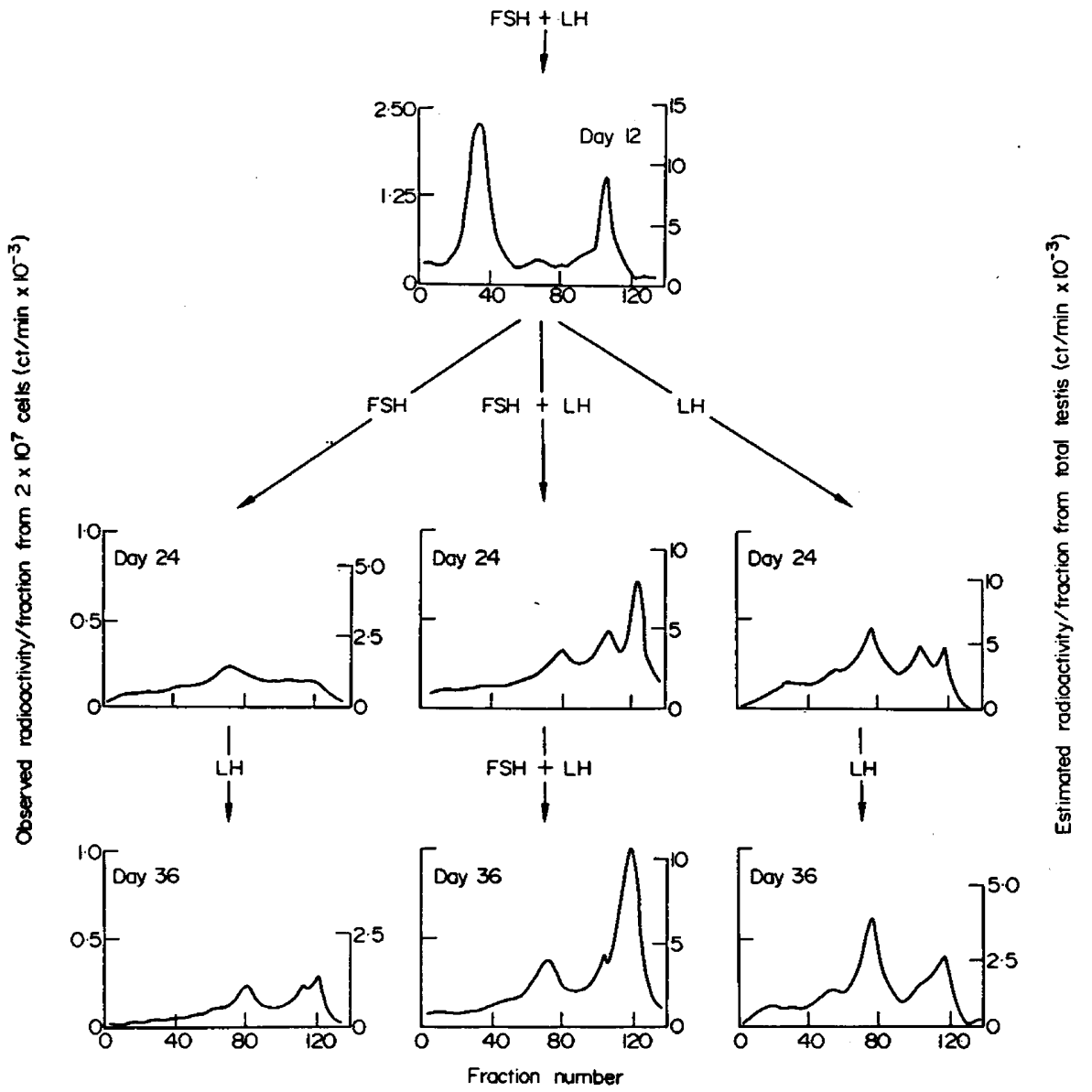

TExT-Fig. 2. See legend for Text-fig. 1.

Whereas $\mathbf{L H}$ was as effective as $\mathbf{L H}+\mathbf{F S H}$ in increasing testicular weight and the other parameters during this period, FSH was significantly $(P<0.05)$ less effective in all cases. Testosterone propionate therapy gave intermediate values, despite the fact that it resulted in greater epididymal weights than LH or FSH + LH therapy (Table 2).

Hormonal requirement during the third cycle of the seminiferous epithelium: progression of pachytene spermatocytes to spermatids (mid-stage)

For this study, rats were given $\mathrm{FSH}+\mathrm{LH}$ for 24 days to generate labelled 


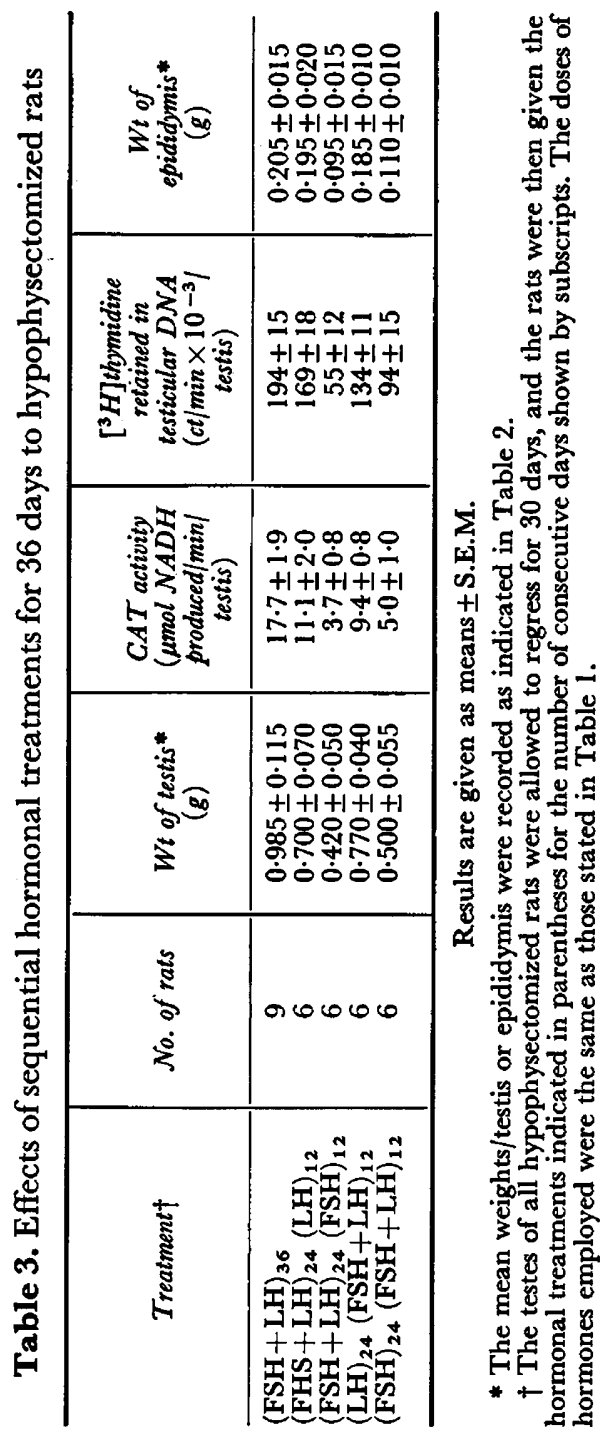


pachytene spermatocytes and then received $\mathrm{FSH}+\mathrm{LH}$ (therapy controls), $\mathrm{LH}$ alone or FSH alone during the subsequent 12 days (see Table 1, Group 2).

Administration of $\mathrm{FSH}+\mathrm{LH}$ for 36 days resulted in a further increase in testicular weight and CAT activity between Days 24 and 36 (Tables 2 and 3). When no FSH was given during Days 24 to $36,(\mathrm{FSH}+\mathrm{LH})_{24}(\mathrm{LH})_{12}$, the testicular weight and CAT activity did not increase, but were maintained at the levels achieved by Day 24. By contrast, cessation of $\mathrm{LH}$ therapy during this period, $(\mathrm{FSH}+\mathrm{LH})_{24}(\mathrm{FSH})_{12}$, was followed by a significant $(P<0.05)$ decline in both testicular weight and CAT activity (Table 3 ).

Tritiated thymidine retention between Days 24 and 36 was similar in rats receiving either $(\mathrm{FSH}+\mathrm{LH})_{36}$ or $(\mathrm{FSH}+\mathrm{LH})_{24}(\mathrm{LH})_{12}$ treatments, whereas $(\mathrm{FSH}+\mathrm{LH})_{24}(\mathrm{FSH})_{12}$ resulted in a much lower $(P<0.01)$ retention of radioactivity (Table 3 ).

Examination of the Staput profiles on Day 36 (Text-fig. 2, 24 days after thymidine) shows that omission of LH therapy between Days 24 and 36 resulted in the absence of any distinguishable peaks. Treatment with $(\mathrm{FSH}+\mathrm{LH})_{24}$ $(\mathrm{LH})_{12}$ also resulted in an abnormal Staput profile. There was an apparently normal peak of radioactivity at Fraction 80 , which contains early round spermatids, but the peak at Fraction 120, which contains more mature labelled spermatids, was greatly diminished compared with that of rats receiving ( $\mathrm{FSH}+$ LH) $)_{36}$. Both FSH and LH are required for the more efficient formation of mid-stage spermatids, as indicated by the amounts of labelled cells appearing in Fraction 120. Treatment with FSH alone appears to be without effect on germinal cell development during the third cycle of the seminiferous epithelium (Text-fig. 2).

Hormonal requirements during the fourth cycle of the seminiferous epithelium: progression of mid-stage spermatids to spermatozoa

Rats were given FSH + LH for 36 days, resulting in the formation of labelled mid-stage spermatids from preleptotene spermatocytes which had been pulselabelled on Day 12. These rats then received FSH + LH (therapy controls), LH or FSH therapy until Day 48 (see Table 1, Group 3). Treatment with $\mathrm{LH}$ alone, $(\mathrm{FSH}+\mathrm{LH})_{36}(\mathrm{LH})_{12}$, was sufficient to maintain the weight of the testes and CAT activity (Table 4). By comparison with controls receiving $\mathrm{FSH}+\mathrm{LH}$, treatment with $\mathrm{FSH}$ alone, $(\mathrm{FSH}+\mathrm{LH})_{36}(\mathrm{FSH})_{12}$, resulted in significant decreases in testicular weight, CAT activity, and the amount of radioactivity retained/testis (Table 4). The lack of FSH therapy resulted in a $20 \%$ decrease in the amount of radioactivity retained in the testis on Day 48 (Table 4), but this decrease was not statistically significant. The Staput profile achieved with the therapy sequence $(\mathrm{FSH}+\mathrm{LH})_{36}(\mathrm{LH})_{12}$ was very similar to that found after FSH+LH for 48 days, or 36 days after thymidine (Text-fig. 3 ). In both cases, there was a pronounced peak of radioactivity at Fraction 120 , corresponding to mature spermatids and spermatozoa. In the absence of LH, $(\mathrm{FSH}+\mathrm{LH})_{36}(\mathrm{FSH})_{12}$, the peak of radioactivity at Fraction 120 was much smaller than that obtained with $\mathrm{FSH}+\mathrm{LH}$, particularly when expressed as radioactivity/fraction from total testis (Text-fig. 3). Microscopic examination 
of sections of testis showed that spermatozoa were present only when LH was administered between Days 36 and 48.

Provided the hypophysectomized rats were treated with $\mathrm{LH}+\mathrm{FSH}$ for 36 days, $\mathrm{LH}$ alone appeared to be adequate for the development of spermatozoa from mid-stage spermatids during the fourth cycle of the seminiferous epithelium.

Cell suspensions were also prepared from epididymides obtained from various groups of rats. Treatment with either $(\mathrm{FSH}+\mathrm{LH})_{48}$ or $(\mathrm{FSH}+\mathrm{LH})_{36}(\mathrm{LH})_{12}$ resulted in the same number of spermatozoa/epididymis (Table 4). By contrast, following treatment with $(\mathrm{FSH}+\mathrm{LH})_{36}(\mathrm{FSH})_{12}$, the epididymides were essentially devoid of spermatozoa (Table 4). Epididymal spermatozoa detected after 48 days of therapy (i.e. 36 days after the administration of $\left[{ }^{3} \mathrm{H}\right]$ thymidine) were unlabelled. The release of unlabelled spermatozoa from the testis and

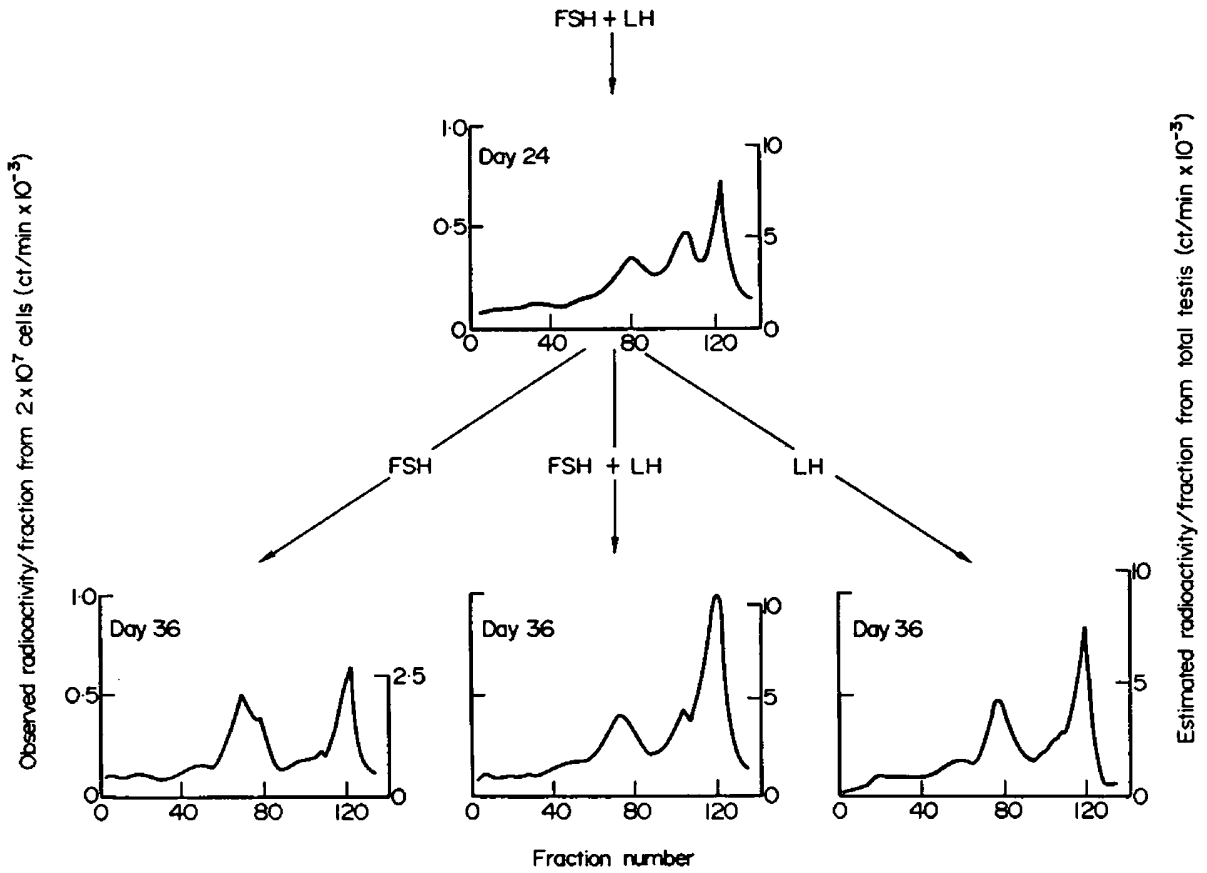

Text-Fig. 3. See legend for Text-fig. 1.

their survival in the epididymis seem to require only LH therapy from Days 36 to 48 , provided $\mathrm{FSH}+\mathrm{LH}$ had been administered during the previous 36 days.

Hormonal requirements for a wave of spermatogenesis in hypophysectomized rats

The ability of the therapy sequences shown in Table 1, Group 1, namely $(\mathrm{LH})_{24}(\mathrm{FSH}+\mathrm{LH})_{12}(\mathrm{LH})_{12},(\mathrm{FSH})_{24}(\mathrm{FSH}+\mathrm{LH})_{12}(\mathrm{LH})_{12}$ and $(\mathrm{TP})_{24}$ $(\mathrm{FSH}+\mathrm{TP})_{12}(\mathrm{TP})_{12}$, to influence the formation of labelled testicular spermatozoa on Day 48 was tested, and the effects of administration of LH or TP 


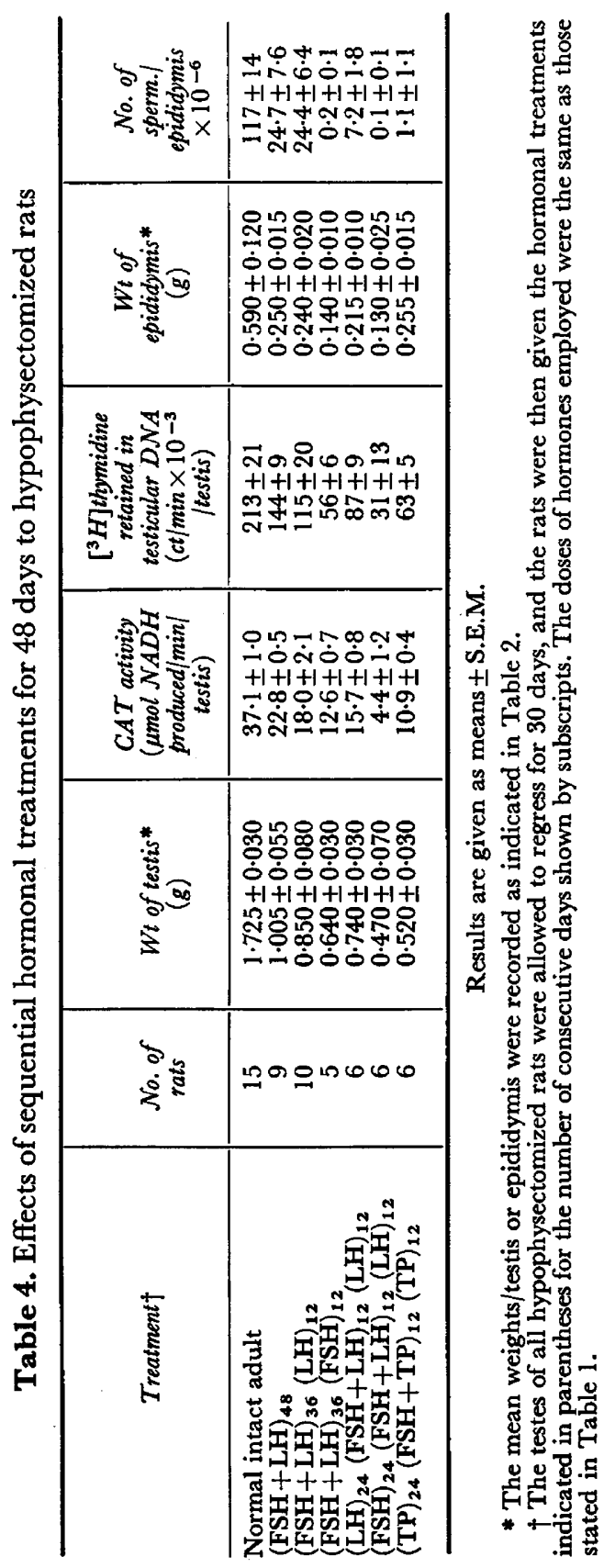


for a further 12 days on ability of these rats to produce labelled epididymal spermatozoa were examined.

The therapy sequence $(\mathrm{LH})_{24}(\mathrm{FSH}+\mathrm{LH})_{12}(\mathrm{LH})_{12}$ gave apparently normal Staput profiles in cells examined 24 and 36 days after $\left[{ }^{3} \mathrm{H}\right]$ thymidine administration (Text-fig. 1). Labelled spermatozoa were detected in testicular cell suspensions in Fraction 120 (Text-fig. 1), and unlabelled spermatozoa were present in epididymal cell suspensions on Day 48 (Table 4). However, testicular weight, CAT activity/testis and the amount of $\left[{ }^{3} \mathrm{H}\right]$ thymidine retained in testis DNA on Days 36 and 48 were all reduced to 60 to $70 \%$ of the levels achieved when FSH + LH were administered continuously (Tables 3 and 4). Even FSH + LH therapy for 48 days to hypophysectomized rats only restored the various criteria examined to $60 \%$ of the normal adult levels (Table 4).

Treatment with the sequence $(\mathrm{FSH})_{24}(\mathrm{FSH}+\mathrm{LH})_{12}(\mathrm{LH})_{12}$ resulted in significantly lower $(P<0.05)$ CAT activities/testis. The retention of labelled testicular DNA on Days 36 and 48 was also lower than that observed after treatment with $(\mathrm{LH})_{24}(\mathrm{FSH}+\mathrm{LH})_{12}(\mathrm{LH})_{12}$ (Tables 3 and 4). The therapy sequence $(\mathrm{FSH})_{24}(\mathrm{FSH}-\mathrm{LH})_{12}$ also gave an abnormal Staput profile on Day 36 , or 24 days after thymidine (Text-fig. 1), with the peak of radioactivity at Fraction 120 being virtually absent. Furthermore, no spermatozoa were detected in testicular or epididymal cell suspensions on Day 48 (Table 4).

In a further experiment, LH was replaced by TP. At the doses employed, the sequence $(\mathrm{TP})_{24}(\mathrm{TP}+\mathrm{FSH})_{12}(\mathrm{TP})_{12}$ was not as effective as the sequence $(\mathrm{LH})_{24}(\mathrm{LH}+\mathrm{FSH})_{12}(\mathrm{LH})_{12}$. On Day 48 (i.e. 36 days after $\left[{ }^{3} \mathrm{H}\right]$ thymidine), the peak of radioactivity at Fraction 120 was markedly reduced in the rats which received TP (Text-fig. 1). Apart from epididymal weight, the other criteria indicated a reduced restoration of testicular function in animals receiving this therapy (Table 4). Few spermatozoa were detected in testicular and epididymal cell suspensions, however, indicating a very inefficient completion of spermatogenesis when TP was substituted for LH.

The above therapy, administering either LH or TP, was continued from Day 48 to Day 60 (see Table 1, Group 1), at which time labelled testicular spermatozoa produced at the end of the fourth cycle should have been transported to the epididymis. The total labelled DNA/epididymis was measured and corrected for labelled DNA in the epididymal cells by subtracting the amount of labelled DNA found in epididymides at 12 or 24 days after injection of $\left[{ }^{3} \mathrm{H}\right]$ thymidine. Only epididymal cells should be labelled in rats injected with $\left[{ }^{3} \mathrm{H}\right]$ thymidine 12 or 24 days previously because labelled spermatozoa could not have been formed by this time. Since similar amounts of labelled DNA were detected in epididymal cells at 12 and 24 days after $\left[{ }^{3} \mathrm{H}\right]$ thymidine administration, data for these control measurements were pooled in calculations shown in Table 5. Assuming that this calculation provides a measure of labelled DNA in spermatozoa in epididymides of rats injected with $\left[{ }^{3} \mathrm{H}\right]$ thymidine 48 days previously, the label incorporation data may be correlated with the observed number of spermatozoa/epididymis (Table 5). The therapy sequences $(\mathrm{LH})_{24}(\mathrm{FSH}+\mathrm{LH})_{12}(\mathrm{LH})_{24}$ and $(\mathrm{TP})_{24}(\mathrm{TP}+\mathrm{FSH})_{12}(\mathrm{TP})_{24}$ each resulted in the presence of labelled spermatozoa in the epididymis on Day 60. The numbers of labelled spermatozoa were significantly less in these animals, 


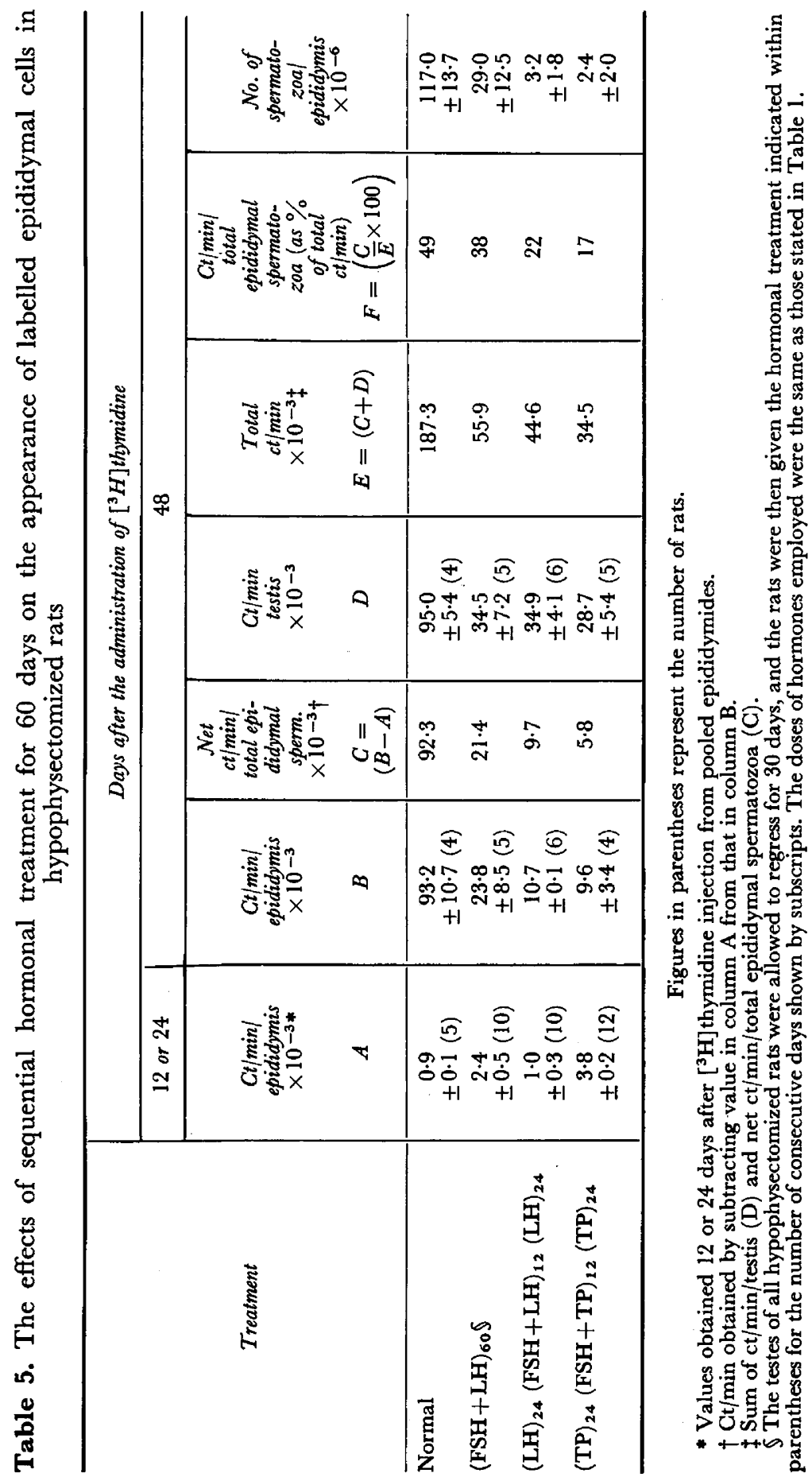


however, than in epididymides from rats given $(\mathrm{FSH}+\mathrm{LH})_{60}$ (Table 5). Treatment with $\mathrm{FSH}+\mathrm{LH}$ for 60 days restored sperm numbers in the epididymides of hypophysectomized rats to levels which were only $25 \%$ of the normal adult level (Table 5). Administration of the sequence (FSH $)_{24}(\mathrm{FSH}+\mathrm{LH})_{12}(\mathrm{LH})_{24}$ did not result in the presence of any spermatozoa or net radioactivity in the epididymis on Day 60 (data not shown).

\section{DISCUSSION}

The complex nature of the hormonal control of spermatogenesis, which has been amply reviewed elsewhere (Clermont \& Harvey, 1967; Steinberger, 1971), remains poorly understood. It is not clear why administration of testosterone or LH alone is sufficient to maintain spermatogenesis at nearly $70 \%$ of normal levels in recently hypophysectomized rats (Clermont \& Harvey, 1967), whereas both FSH and LH are required to restore spermatogenesis in long-term hypophysectomized rats, as in the studies reported in this paper. With the hormone doses employed, various degrees of restoration were achieved, depending upon the criterion evaluated. In rats receiving both FSH and LH for 48 days, there was complete restoration of the specific activity of testicular CAT $(21.5 \mu \mathrm{mol} \mathrm{NADH} / \mathrm{min} / \mathrm{g}$ wet weight testis $)$, but the level/testis was only $61 \%$ of normal because the testis weight was not fully restored in the treated, hypophysectomized rats (Table 4). The significance of CAT as a marker enzyme for spermatocytes and spermatids has been discussed previously (Vernon et al., 1971).

With respect to the retention of DNA-labelled testicular cells, the hormonetreated rats had levels about $68 \%$ of normal, but the numbers of spermatozoa/ epididymis were less than $25 \%$ of those found in intact rats (Table 4). On the other hand, the restoration of normal Staput profiles, which provide a measure of the progress of pulse-labelled preleptotene spermatocytes during spermatogenesis (Lam et al., 1970; Go et al., 1971a), appeared essentially complete in hypophysectomized rats treated with FSH + LH (Go et al., 1971b; Text-figs 2 and 3).

The degree of restoration achieved seems to depend on differences between the total levels and concentrations of the variables being assessed. With daily doses of $100 \mu \mathrm{g} \mathrm{NIH}$ ovine FSH and $\mathrm{LH}$, the efficiency of production of spermatozoa was clearly far less than that observed in normal rats. This may be a reflection of inadequate levels of gonadotrophic hormones, the deficiency of other hypophysial hormones or both.

In considering the requirement for FSH or LH during different cycles of the seminiferous epithelium, the effects of various treatments have been compared with values obtained for animals receiving $\mathrm{FSH}+\mathrm{LH}$ for the equivalent period. This was necessary because no one has been successful in providing a therapy which reverses all the changes in the testis which occur during regression after hypophysectomy.

A promising criterion to investigate in detail seemed to be the change in Staput profiles of testicular cells obtained from rats at various times after the administration in vivo of a pulse of $\left[{ }^{3} \mathrm{H}\right]$ thymidine to label the DNA of pre- 
leptotene spermatocytes and other less advanced germinal cells. This technique permits an approach towards differentiation kinetics under various conditions (Lam et al., 1970; Go et al., 1971a).

Comparable numbers of labelled pachytene spermatocytes, corresponding to Fraction 30 in the Staput fractionation, appeared 12 days after $\left[{ }^{3} \mathrm{H}\right]$ thymidine administration in hypophysectomized rats treated with $\mathrm{FSH}+\mathrm{LH}$, or with FSH, LH or TP alone (Text-fig. 1). An inappreciable number of labelled pachytene cells appeared in untreated hypophysectomized animals. Data obtained with Staput profile analyses have been confirmed with radioautographic determinations and by differential cell counts of Staput fractions (Go et al., 1971a, b; Meistrich et al., 1973). These data agree with calculations from the kinetic data of Clermont \& Harvey (1965), from which it can be deduced which cells should be labelled at any particular time after the administration of $\left[{ }^{3} \mathrm{H}\right]$ thymidine.

The failure of FSH therapy alone to restore testicular weight or CAT levels (Table 2), and the subsequent inability of FSH + LH therapy to permit further progression of labelled pachytene spermatocytes to spermatids in these rats (Text-fig. 1) indicate that FSH alone is not able to effect the production of sufficient numbers of competent pachytene spermatocytes to complete spermatogenesis. Similarly, FSH therapy during the third cycle of the seminiferous epithelium was insufficient to allow completion of meiosis of labelled pachytene cells previously produced in hypophysectomized rats treated with FSH $+\mathrm{LH}$ (Text-fig. 2), or to restore testicular weights, CAT levels or labelled cell retention (Table 3 ).

On the other hand, supplementation of LH therapy with FSH was necessary to achieve the most efficient completion of meiosis and formation of normal Staput profiles representative of mid-stage spermatids (Table 3 and Text-fig. 2).

When hypophysectomized rats were treated with $\mathrm{FSH}+\mathrm{LH}$ for 36 days, subsequent therapy with $\mathbf{L H}$ alone during the period corresponding to the fourth cycle of the seminiferous epithelium was sufficient to permit the same amounts of labelled spermatozoa to be formed as when FSH was also given (Text-fig. 3 and Table 4). By other criteria employed, LH alone during this interval was similarly observed to be as efficacious as LH +FSH (Table 4). We therefore conclude that in the properly prepared tubule, FSH is not required for the completion of spermiogenesis. This conclusion differs from that offered by Steinberger (1971), based on the fact that FSH, present in PMSG, appeared to be required for the completion of spermiogenesis in oestrogentreated rats given testosterone (Steinberger \& Duckett, 1967). In these studies, Steinberger \& Duckett (1967) administered PMSG for 30 days or longer. The cessation of spermatogenesis which occurs after oestrogen treatment, however, is not necessarily the same as that which occurs in long-term hypophysectomized animals. In addition, the lengthy period during which PMSG was administered by Steinberger \& Duckett (1967) precludes conclusions concerning the precise times at which FSH was acting, and ignores the possible contributions of LH present in PMSG. From our results, we consider that FSH and LH or androgen are required to permit the efficient completion of meiosis and formation of early spermatids. The absence of these hormones would be reflected 
in a decreased generation of late spermatids. Until such time as the concentrations of mid-stage spermatids became optimal, there would be an FSH requirement. We interpret the data presented in Text-fig. 3 and Table 4 to indicate that under the conditions described, FSH was not required during the fourth cycle to restore spermiogenesis in hypophysectomized rats. On the other hand, supplementation of LH therapy with FSH during each of the first three cycles seemed to enhance the efficiency of the restoration of spermatogenesis, as evaluated by some of the criteria cited in Tables 4 and 5 . The data do not permit the conclusion that FSH is required during only one cycle of the seminiferous epithelium. It appears essential, however, during the third cycle, and acts additively with LH during the initial cycles of the seminiferous epithelium to increase the overall efficiency of spermatogenesis. Treatment with FSH alone was inadequate to permit functional restoration of spermatogenesis during any of the cycles, although it did permit the progress of pulse-labelled preleptotene spermatocytes to the mid-pachytene stage (Fraction 30 of Textfig. 1).

Our results emphasize the importance of LH, presumably acting through stimulation of testosterone formation, in spermatogenesis. Treatment with $\mathrm{LH}$ would allow testosterone levels in the tubules to be higher than in the systemic circulation, since androgens produced by the interstitial cells could diffuse directly into the tubules. Treatment with doses of testosterone high enough to achieve levels comparable to those obtained in the spermatic vein after treatment with $\mathrm{LH}$ should, in principle, be capable of duplicating the effects of $\mathrm{LH}$ treatment.

Cessation of LH therapy in any cycle resulted in alteration of the Staput profiles, rapid loss of labelled germinal cells and marked decreases in CAT levels, presumably in association with the reduced formation of spermatocytes and spermatids, and with their rapid loss. It appears that high levels of androgens are required to permit all stages of spermatogenesis to proceed efficiently. Similar conclusions may be drawn from the data of Clermont \& Morgentaler (1955) and Clermont \& Harvey (1967). It nevertheless appears, both from the literature and from the results presented above, that nearly all stages of spermatogenesis can proceed to some extent when the hormonal environment is less than optimal. It is generally accepted that the duration of each cycle of the seminiferous epithelium of the rat is not altered by hypophysectomy or by hormonal therapy (Clermont \& Harvey, 1965). The hormones may therefore be generally necessary for efficient spermatogenesis, but it is conceivable that all steps can occur to some extent in the absence of hormones. The very low number of spermatozoa in the epididymis in rats given sub-optimal hormonal replacement therapy (Table 5) attests to the importance of hormones in permitting the overall process to occur effectively, but these data provide no insight into the sites of hormone action involved in spermatogenesis.

The possible rôle of FSH in spermatogenesis is further complicated by the results of Boccabella (1963), who reported that prolonged administration of testosterone to long-term hypophysectomized rats resulted in formation of spermatozoa by some of the tubules in some of the treated animals. The possible presence of endogenous FSH in these animals was not ruled out. 
It has been shown that FSH acts on Sertoli cells to increase adenyl cyclase activity, but FSH has no known effect on Leydig cells or on germinal cells (Dorrington \& Fritz, 1974; Dorrington et al., 1974). Treatment with FSH can also reverse the cytological changes in Sertoli cells which occur after hypophysectomy (Lostroh et al., 1963; Murphy, 1965; Lostroh, 1969) or following oestrogen treatment (Lacy \& Lofts, 1965). In addition, FSH administration in vivo is reported to increase protein and RNA synthesis by testicular preparations (Means \& Hall, 1971). The Sertoli cells are thought to be the cells in the tubule responsible for forming and maintaining the blood-testis barrier, and for the formation of tubule fluid (Dym \& Fawcett, 1970; Setchell \& Waites, 1971; Fawcett, 1974). Sertoli cells have also been implicated in the formation and synthesis of an androgen-binding protein (ABP) which is secreted into tubular fluid (French \& Ritzen, 1973; Vernon et al., 1973, 1974). The addition of FSH in vitro has recently been shown to increase ABP formation by isolated Sertoli cells in culture (Fritz et al., 1974), and FSH administration in vivo to hypophysectomized rats results in increased ABP levels in testis (Hansson et al., 1973; Vernon et al., 1973, 1974).

The relationships of these observations to the rôle of FSH in acting synergistically with androgens to restore spermatogenesis in hypophysectomized rats remain to be determined.

It may be conjectured that some if not all the impairments in spermatogenesis observed after hypophysectomy, and partial restorations following hormonal therapy, are indirect manifestations of alterations in the tubular environment in which germinal cell development is occurring. If this is the case, the profound effects of FSH and androgens on spermatogenesis may be indirect ones, mediated through their influence on Sertoli cell function.

\section{ACKNOWLEDGMENTS}

This work was supported by grants from the Medical Research Council of Canada and the Banting Research Foundation. The expert technical assistance of Mrs Deanne Lalande and Mrs Irene Haltrecht is gratefully acknowledged, as is the skilful help offered by Miss Barbara Smith in typing and assembling this manuscript. While this work was being conducted, R.G.V. held successive postdoctoral fellowships from the Canadian MRC and the Banting Research Foundation, while the postdoctoral fellowship support of V.L.W.G. was provided by the Mayo Foundation. The samples of FSH and LH were kindly supplied by the National Institutes of Health through the courtesy of Dr R. W. Bates.

\section{REFERENCES}

Albert, A. (1961) The mammalian testis. In Sex and Internal Secretions, 3rd edn, vol. I, pp. 305-365. Ed. W. C. Young. Williams \& Wilkins, Baltimore.

Boccabella, A. B. (1963) Reinitiation and restoration of spermatogenesis with testosterone propionate and other hormones after a long-term post-hypophysectomy regression period. Endocrinology, 72, 787-798.

Clermont, Y. (1972) Kinetics of spermatogenesis in mammals: seminiferous epithelium cycle and spermatogonial renewal. Physiol. Rev. 52, 198-236.

Clermont, Y. \& Harvey, S. C. (1965) Duration of the cycle of the seminiferous epithelium of normal, hypophysectomized and hypophysectomized-hormone treated albino rats. Endocrinology, 76, 80-89.

Clermont, Y. \& Harvey, S. C. (1967) Effects of hormones on spermatogenesis in the rat. CIBA Fdn Collog. Endocr., Endocrinology of the Testis, 16, 173-196. 
Clermont, Y. \& Morgentaler, H. (1955) Quantitative study of spermatogenesis in the hypophysectomized rat. Endocrinology, 57, 369-382.

Curuly, E. \& Cutuly, E. C. (1940) Observations on spermatogenesis in rats. Endocrinology, 26, 503-507.

Dorrington, J. H. \& FrITz, I. B. (1974) Effects of gonadotropins on cyclic AMP production by isolated seminiferous tubule and interstitial cell preparations. Endocrinology, 94, 395-403.

Dorrington, J. H., Roller, N. \& Fritz, I. B. (1974) The effects of FSH on cell preparations from the rat testis. In Hormone Binding and Activation in Testis, Eds. M. Dufau and A. R. Means. Plenum Press, New York (in press).

Dulbecco, R. \& Vogt, M. (1954) Plaque formation and isolation of pure lines with poliomyelitis viruses. 7. exp. Med. 99, 167-199.

Dym, M. \& Fawaetr, D. W. (1970) The blood-testis barrier in the rat and the physiological compartmentation of the seminiferous epithelium. Biol. Reprod. 3, 308-326.

Fawcet, D. W. (1974) The ultrastructure and functions of the Sertoli cell. In Handbook of Physiology, Section 7 : Endocrinology, Male Reproduction. Waverly Press, Baltimore, Md (in press).

French, F. S. \& Ritzen, E. M. (1973) A high affinity androgen-binding protein (ABP) in rat testis: evidence for secretion into efferent duct fluid and absorption by epididymis. Endocrinology, 93, 88-95.

Fritz, I. B., Kopec, B., LAM, K. \& Vernon, R. G. (1974) Effects of FSH on levels of androgen binding protein in the testis. In Hormone Binding and Activation in Testis. Eds. M. Dufau and A. R. Means Plenum Press, New York (in press).

Go, V. L. W., Vernon, R. G. \& Fritz, I. B. (1971a) Studies on spermatogenesis in rats. I. Application of the sedimentation velocity technique to an investigation of spermatogenesis. Can. $\mathcal{F}$. Biochem. 49, 753-760.

Go, V. L. W., Vernon, R. G. \& Fritz, I. B. (1971b) Studies on spermatogenesis in rats. III. Effects of hormonal treatment on differentiation kinetics of the spermatogenic cycle in regressed hypophysectomized rats. Can. 7. Biochem. 49, 768-775.

Hansson, V., Reusch, E., Trygstad, O., Torgersen, O., Ritzen, E. M. \& French, F. S. (1973) FSH stimulation of testicular androgen binding protein. Nature, New Biology, 246, $56-57$.

LACY, D. \& LoFTs, B. (1965) Studies on the structure and function of the mammalian testis. I. Cytological and histochemical observations after continuous treatment with oestrogenic hormone and the effects of FSH and LH. Proc. R. Soc. B, 162, 188-197.

Lam, D. M. K., Furrer, P. \& Bruce, W. R. (1970) The separation, physical characterization, and differentiation kinetics of spermatogonia cells of the mouse. Proc. natn. Acad. Sci. U.S.A.65, 192-199.

LostroH, A. J. (1969) Regulation by FSH and ICSH (LH) of reproductive function in the immature male rat. Endocrinology, 85, 438-445.

Lostron, A. J. (197I) Parameters in the biology of spermatogenesis. In Laboratory Tests in the Diagnosis and Investigation of Endocrine Function, pp. 285-294. Ed. R. F. Escamilla. F. A. Davis, Philadelphia.

Lostroh, A. J., Johnson, R. \& Jordan, C. W., JR (1963) Effect of ovine gonadotrophins and antiserum to interstitial cell-stimulating hormone on the testis of the hypophysectomized rat. Acta endocr., Copenh. 44, 536-544.

Means, A. R. \& Hall, P. F. (1971) Protein biosynthesis in the testis. VI. Action of follicle-stimulating hormone on polyribosomes in immature rats. Cytobios, 3, 17-24.

Meistrich, M. L., Bruce, W. R. \& Clermont, Y. (1973) Cellular composition of fractions of mouse testis cells following velocity sedimentation separation. Expl Cell Res. 79, 213-227.

Monesi, V. (1962) Autoradiographic study of DNA synthesis and the cell cycle in spermatogonia and spermatocytes of mouse testis using tritiated thymidine. 7. Cell Biol. 14, 1-18.

Monesi, V. (1965) Synthetic activities during spermatogenesis in the mouse. Expl Cell Res. 39, $197-224$.

Murphy, H. D. (1965) Sertoli cell stimulation following intratesticular injections of FSH in the hypophysectomized rat. Proc. Soc. exp. Biol. Med. 118, 1202-1205.

Nelson, W. O. (1937) Some factors involved in the control of the gametogenic and endocrine functions of the testis. Cold Spring Harb. Symp. quant. Biol. 5, 123-135.

Setchell, B. P. \& Waites, G. M. H. (1971) The exocrine secretion of the testis and spermatogenesis. 7. Reprod. Fert., Suppl. 13, 15-27.

Steinberger, E. (1971) Hormonal control of mammalian spermatogenesis. Physiol. Rev. 51, 1-22.

Steinberger, E. \& Duckett, G. E. (1967) Hormonal control of spermatogenesis. F. Reprod. Fert., Suppl. 2, 75-87.

Vernon, R. G., Go, V. L. W. \& Fritz, I. B. (1971) Studies on spermatogenesis in rats. II. Evidence that carnitine acetyltransferase is a marker enzyme for the investigation of germ cell differentiation. Can. 7. Biochem. 49, 761-767.

Vernon, R. G., Kopec, B. \& Fritz, I. B. (1973) Studies on the distribution of the high-affinity testosterone binding protein in rat testis seminiferous tubules. $\mathcal{F}$. Endocr. 57, iip.

Vernon, R. G., Kopec, B. \& Fritz, I. B. (1974) Observations on the binding of androgens by rat testis, seminiferous tubules and testis extracts. F. cell. molec. Endocr. 1, 167-187. 